KINGA KRAWIECKA

Wydział Nauk Pedagogicznych

Forum Pedagogiczne

$9(2019) 2$, cz. 2

Uniwersytet Kardynała Stefana Wyszyńskiego

Wpłynęło: 20.10.2019

Warszawa

ORCID ID: http://orcid.org/oooo-0oo2-3516-4676

\title{
DŹWIĘKOWE AKTYWIZOWANIE RUCHU W PRZESTRZENI. MODEL PRACY Z UCZNIAMI Z NIEPEŁNOSPRAWNOŚCIĄ INTELEKTUALNĄ
}

Streszczenie: $\mathrm{W}$ artykule przedstawiono aktywizowanie ruchu w przestrzeni za pomocą różnego rodzaju dźwięków, prezentując autorski model pracy z uczniami z niepełnosprawnością intelektualną w stopniu umiarkowanym i znacznym. Pierwsza część - teoretyczna, w której zaprezentowano znaczenie muzyki i dźwięku dla rozwoju i terapii, stała się wstępem do drugiej - o charakterze praktycznym, w której przedstawiono dźwięki aktywizujące ruch i poruszanie się w przestrzeni uczniów z niepełnosprawnością intelektualną. Posiłkując się autorskim modelem zajęć dźwiękowo-ruchowych, którego odbiorcami byli uczniowie z niepełnosprawnością intelektualną przedstawiono charakterystykę czterech modułów zajęć z uszczegółowieniem modułu IV, zatytułowanego: „Ruch na ziemi - piesi i kierowcy". Fundamentalnym jego celem było aktywizowanie i prowokowanie określonego - prawidłowego i świadomego ruchu w przestrzeni poprzez świadomie dobrane i zastosowane dźwięki. Ruch aktywizowany był określonym rodzajem dźwięku, wzbogaconym o prosty obraz i słowo - pisane i wypowiadane, dzięki czemu każdy uczeń z niepełnosprawnością doświadczalnie zdobywał wiedzę i umiejętność rozumienia przestrzeni i świadomego poruszania się w niej.

Słowa kluczowe: muzyka; dźwięk; ruch w przestrzeni; dźwiękowe aktywizowanie; uczeń $\mathrm{z}$ niepełnosprawnością intelektualną.

\section{Wprowadzenie}

Muzyka ma wiele możliwości zastosowania w pracy z człowiekiem. Po pierwsze, oddziałuje na jego rozwój psychoruchowy, a po drugie - dociera do tych sfer rozwoju, które w jakimś sensie niedomagają i sprawia, że osoba komunikuje to, czego nie może bądź nie chce wyrazić słowem. Komunikuje zatem gestem, ruchem manualnym lub też ruchem całego ciała. Dźwięk, który odbiera słuchowo, oddziałuje na jej reakcję ruchową. Dźwięk zaciekawia, a następnie prowokuje, 
stymuluje, aktywizuje do czynności ruchowej. Tym bardziej potrzebny jest w pracy z uczniami z niepełnosprawnością intelektualną, ponieważ „może stać się żywym zrozumiałym doświadczeniem, nie wymagającym myślenia abstrakcyjnego [...]. Aktywność muzyczna może zachęcić dziecko niepełnosprawne do ekspresywnego ruchu rąk, nóg lub ekspresji związanej z wydawaniem dźwięków, zaś struktury melodyczno-rytmiczne wspierają dziecko i wprowadzają porządek w jego działanie, pomagają kontroli" (Nordoff, Robbins 2008, s. 18).

W artykule ukazano sposoby dźwiękowego aktywizowania ruchu dziecka z niepełnosprawnością intelektualną - ruchu refleksyjnego, intencjonalnego, który wyznacza prawidłowy kierunek poruszania się w przestrzeni. Zaprezentowany czteromodułowy cykl zajęć dźwiękowo-ruchowych stał się zatem określonym modelem pracy z uczniem $\mathrm{z}$ niepełnosprawnością intelektualną $\mathrm{w}$ stopniu umiarkowanym i znacznym, którego podstawą był rozwój i usprawnianie ruchu w przestrzeni okołoosobowej i bliskiej, a to z kolei może w przyszłości przyczynić się do bezpiecznego funkcjonowania w przestrzeni społecznej.

\section{Muzyka i dźwięk - znaczenie dla rozwoju i terapii}

Muzyka, po pierwsze, jest ważnym medium oddziałującym na dwa podstawowe procesy: rozwój i terapię. Po drugie, jest ważnym medium oddziałującym na każdym etapie rozwoju osoby.

Rozpocznę od przedstawienia znaczenia muzyki i dźwięku dla rozwoju psychoruchowego człowieka. Muzyka towarzyszy jednostce we wszystkich fazach jej rozwoju, od okresu niemowlęctwa, przez okres dzieciństwa, wieku młodzieńczego, aż po dorosłość. Ma znaczenie dla rozwoju dziecka jeszcze przed jego narodzeniem, szczególnie oddziałując na procesy komunikacji. Pisze o tym Hans-Helmut DeckerVoigt w podręczniku Lehrbuch Musiktherapie następująco: „Percepcja muzyki zaczyna się już w okresie prenatalnym, w ciele matki [...]. Wówczas poznaje ono najważniejsze muzyczne parametry: rytm, z jakim bije serce matki oraz wykonywane przez nią wdechy i wydechy; dźwięk i melodię odgłosów ciała matki [...], ale również dochodzące do dziecka z zewnątrz odgłosy codziennego życia, głos ojca, muzyka z otoczenia; dynamikę, która zawiera i pozwala przeżyć kontrasty, wyrażana tempem, głośnością i wysokością tonu wymienionych wyżej zjawisk” (cyt. za: Stegemann 2015, s. 69). W okresie dzieciństwa muzyka i dźwięk oddziałują na sferę rozwoju fizycznego, poznawczego, emocjonalno-społecznego. Dźwięki prezentowane w różnym tempie i z różną głośnością angażują dziecko motorycznie. Jest ono aktywizowane zarówno pod względem ruchu całego ciała, jak i ruchów precyzyjnych ręki. Dziecko doskonali stopniowo „ruchy postawno-lokomocyjne, jak i ruchy warunkujące sprawne wykonanie czynności na przedmiotach [...]. Jest to okres, w którym następuje wyjątkowy przyrost w zakresie koordynacji ruchów" (Makris, Umiastowska 2001, s. 8). Oprócz poszerzania i doskonalenia umiejętności ruchowych dziecka, muzyka i dźwięk oddziałują na jego rozwój poznawczy. 
Ton, harmonia i rytm dźwięków zmuszają do koncentrowania uwagi - dźwięk zaciekawia. Dziecko zaczyna słuchać i słyszeć określone dźwięki. Różnicuje je i syntetyzuje z wcześniej poznanymi, dokonując procesu myślowego. Tworzy własne rytmy - na początku jako odtwórca (naśladowca) z uaktywnieniem nie tylko zmysłu słuchu, lecz także zmysłu wzroku, następnie jako odkrywca, a w efekcie końcowym jako samodzielny twórca. Kreując autorskie improwizacje muzyczne oraz ilustrując ruchowo określony dźwięk lub temat muzyczny, wykorzystuje i rozwija zdolności wyobrażeniowe. „Dzięki tej atrakcyjnej formie zajęć intensyfikują się procesy poznawcze, takie jak: spostrzeganie, wyobrażenia, myślenie. Wyrabia się też zdolność koncentracji uwagi, kształci szybka orientacja oraz pamięć, pobudza aktywność" (Krzywoń 2008, s. 53). Muzyka i dźwięk dostarczają również przeżyć emocjonalnych. Będąc podatnym na bodźce muzyczne, dziecko wzrusza się, interpretując muzyczne nastroje i obrazując je ruchowo: całym ciałem lub manualnie. Emocjonalne i estetyczne współprzeżywanie muzyki bądź jej dźwiękowe współtworzenie w grupie rozwija lub umacnia autentyczne więzi społeczne. „Zespołowe czynności muzyczne tworzą interakcje społeczne, w których dziecko zajmuje prospołeczne postawy, wykazuje zdyscyplinowanie i odpowiedzialność. Kontakt z muzyką i stosunki społeczne, jakie się przy tej okazji tworzą, kształtują bezinteresowne więzi" (Krzywoń 2008, s. 48). Treść emocjonalna, jaką niosą ze sobą muzyka i dźwięk, ma fundamentalne znaczenie dla osób w wieku młodzieńczym i dorosłych. Aktywizuje i pobudza lub odpręża i wycisza. Wprowadza w pogodny nastrój, stanowiąc formę zabawy i rozrywki, budującej lub korygującej relacje interpersonalne. Należy podkreślić jej rolę w życiu i funkcjonowaniu młodzieży, a dokładniej - w kształtowaniu tożsamości i regulacji emocji. Karin E. Sauer, Gottfried M. Barth i Gunther Klosinski piszą o tym następująco: „Muzyka umożliwia młodym ludziom konfrontowanie się z różnymi aspektami swojej tożsamości (dotyczącymi na przykład seksualności, uczuć, krytyki instytucji). Może się także stać środkiem do wyrażania emocji i przyczynić się do ich porządkowania i różnicowania" (cyt. za: Stegemann 2015, s. 72).

W związku z powyższym, muzyka jest środkiem pełniącym ważną rolę w życiu człowieka niezależnie od jego wieku, zmienia się natomiast specyfika owej roli. „Muzyka jest doświadczeniem uniwersalnym, ponieważ każdy może je dzielić. Jej podstawowe elementy: melodia, harmonia i rytm oddziałują na nas i pobudzają w nas określone funkcje psychofizyczne. Dzieje się tak, ponieważ przekaz i siła wyrazu, jakie niesie muzyka, zawierają cały zakres ekspresji emocjonalnej" (Nordoff, Robbins 2008, s. 17).

Muzyka i dźwięk mają swoiste zastosowanie również w terapii. Nie tyle rozwijają procesy psychoruchowe, co je usprawniają, korygują lub leczą, bowiem z języka greckiego słowo therapeuéin oznacza „leczenie” (Abramowiczówna 1960). Wykorzystując szeroki wachlarz aktywności i środków wyrazu muzycznego, muzykoterapia dzieli się na kilka rodzajów, a mianowicie: 
- „muzykoterapia kliniczno-diagnostyczna, w zakres której wchodzą działania podejmowane przez specjalistów z dziedziny medycyny;

- muzykoterapia naturalna, gdzie podstawowym materiałem muzycznym są dźwięki natury, np. szum potoku górskiego czy śpiew ptaków;

- muzykoterapia spontaniczna, będąca wyrazem przeżywanych emocji;

- muzykoterapia adoptowana, wykorzystująca przypadkowy materiał muzyczny (np. muzykę nadawaną przez radio) w celu uspokojenia czy relaksu;

- muzykoterapia profilaktyczna, stosowana w celu zapobiegawczym, wykorzystująca odpowiedni materiał muzyczny w celu zaktywizowania lub uspokojenia pacjenta" (Wójcik-Standio 1999, s. 35, cyt. za: Konieczna 2014, s. 44). Zasadniczym celem terapii poprzez muzykę i dźwięk jest stymulowanie emocji oraz pośredniej komunikacji. Jednostka w działaniu muzycznym okazuje osobiste przeżycia, dostarczając informacji o tym, czego nie może, nie potrafi bądź nie chce wyrazić werbalnie. „Terapia przez muzykę umożliwia komunikację niewerbalną, dzięki której uczestnik może przepracować swoje problemy bez użycia słów. Taki sposób artykułowania problemów polega na aktywności muzycznej z pominięciem werbalnych środków wyrazu" (Konieczna 2014, s. 46). Aby móc realizować cele muzykoterapeutyczne, należy posługiwać się właściwym sposobem oddziaływania, opartym na metodach i technikach muzykoterapeutycznych. Metodami muzykoterapeutycznymi określa się „,ztery postacie muzycznego przeżycia/przepracowania: improwizację (improvisation), reprodukcję (recreation), komponowanie (composition) i odbiór (listening)" (Bruscia 1998, cyt. za: Stegemann 2015, s. 77). Natomiast techniki muzykoterapeutyczne definiuje się jako „pojedyncze działania (operation) albo interakcje, które są stosowane przez terapeutę w celu wywołania u pacjenta bezpośredniej reakcji lub przekształcenia chwilowego przeżycia w proces (to shape)" (Bruscia 1998, cyt. za: Stegemann 2015, s. 77).

Niezależnie od tego, w jakim celu wykorzystujemy muzykę i dźwięk (rozwojowym czy terapeutycznym), jakimi metodami czy technikami pracy się posługujemy i kto jest podmiotem muzycznej aktywności (dziecko czy osoba dorosła, człowiek w normie intelektualnej, człowiek z niepełnosprawnością czy człowiek z chorobą), to muzyka i dźwięk były, są i pozostaną wartościowym bodźcem do kontaktu ze światem i z drugim człowiekiem. Clive Robbins, współtwórca programu nauczania w zakresie muzykoterapii kreacyjnej, stosowanej wśród dzieci i osób dorosłych z niepełnosprawnością intelektualną, napisał: „Świat się zmienia, tak jak i nasza świadomość, idące naprzód życie przynosi nieustannie rozmaite oczekiwania i nowe nadzieje, ale jedno nie zmienia się nigdy: w twórczości muzycznej i w samej muzyce drzemie wielki potencjał uzdrawiający i dający siłę" (Nordoff, Robbins 2008, s. 16).

Muzyka i dźwięk dają siłę, motywację do działania, a zatem aktywizują jednostkę ludzką do rozwoju lub terapii. Wspomniałam, że dźwięki prezentowane w różnym tempie i z różną głośnością angażują dziecko motorycznie. Chcę jednak zwrócić szczególną uwagę na wykorzystanie dźwięków do prowokowania - aktywizowania ruchu 
w przestrzeni - ruchu dziecka z niepełnosprawnością intelektualną. Stosowanie różnych rodzajów dźwięków: wysokiego - niskiego, długiego - krótkiego, głośnego - cichego, pojedynczego lub występującego w kombinacjach oraz w różnym tempie, prowokuje - aktywizuje określony ruch w przestrzeni: do przodu - do tyłu, w prawo - w lewo, do góry - na dół, tym samym rozwijając lub usprawniając świadomość przestrzeni i umiejętność prawidłowego poruszania się w niej. Zatem przedstawienie znaczenia muzyki i dźwięku dla ogólnego rozwoju i terapii osoby na różnych etapach jej rozwoju daje możliwość zaprezentowania znaczenia określonych dźwięków dla aktywizowania ruchu dziecka z niepełnosprawnością intelektualną - ruchu refleksyjnego, intencjonalnego, który wyznacza prawidłowy kierunek poruszania się w przestrzeni. W związku z powyższym chcę zaakcentować aktywizujące znaczenie dźwięku dla wywołania określonego ruchu, które przyczynia się do rozwijania i usprawniania (terapii) prawidłowego poruszania się w przestrzeni.

\section{Dźwięki aktywizujące ruch i poruszanie się w przestrzeni uczniów $\mathrm{z}$ niepełnosprawnością intelektualną}

Muzyka jest niezbędnym medium aktywizującym rozwój uczniów z niepełnosprawnością intelektualną, ponieważ ,jest sztuką uniwersalną, posługującą się głosem i instrumentem. Przemawia do człowieka poprzez zjawiska słuchowe, będąc nośnikiem ludzkich uczuć, emocji, nastrojów" (Chyła-Szypułowa 2009, s. 180). Należy zastanowić się jednak, w jaki sposób przebiega aktywizowanie ruchu i poruszania się w przestrzeni uczniów z niepełnosprawnością intelektualną z wykorzystaniem różnych rodzajów dźwięków.

W pedagogice aktywizowanie jest sposobem działania, które ma na celu zwiększenie dotychczasowej aktywności osób, w obszarze mojej praktyki - uczniów z niepełnosprawnością intelektualną. Określa się ten proces jako „zespół zabiegów dydaktyczno-wychowawczych, w wyniku których wzrasta u wychowanków zainteresowanie, samodzielność i aktywność poznawcza, wytwórcza, społeczna i kulturalna" (C. Kupisiewicz, M. Kupisiewicz 2009, s. 9). Jest to czynność, która rozpoczyna się od zaciekawienia ucznia, rozbudzenia jego ciekawości poznawczej. Uczeń zainteresowany tym, co będzie motywem przewodnim zajęć edukacyjnych, jest gotowy do działania. Reaguje, współpracuje, starając się być samodzielnym w czynnościach wytwórczych. Pisząc zatem o procesie dźwiękowego aktywizowania ucznia $\mathrm{z}$ niepełnosprawnością intelektualną do wykonania określonych ruchów w przestrzeni, niezbędne jest odwołanie się do trzech współpracujących ze sobą bloków funkcjonalnych, które Katarzyna Klimek-Markowicz nazywa zespołami: zespół aktywności, zespół przetwarzania oraz zespół realizacji. Zadaniem pierwszego bloku funkcjonalnego - zespołu aktywności jest „regulowanie stanu czuwania, poziomu gotowości do działania, reagowania i odbierania bodźców" (Klimek-Markowicz 2016, s. 289). Uczniowie z niepełnosprawnością intelektualną 
funkcjonują na różnych poziomach aktywności. K. Klimek-Markowicz wyróżnia cztery jej poziomy, a mianowicie:

- „reaktywność w normie - pozwala na odbiór bodźców, jest adekwatna do zadania;

- nadreaktywność - występuje, kiedy osoba ma wzmożony napęd psychoruchowy, jest nadmiernie aktywna w sposób niepozwalający jej na odbiór informacji; taki rodzaj trudności może występować u osób z nadruchliwością (ADHD);

- obniżona reaktywność - może występować u dziecka, które przez cały dzień jest senne, słabo reaguje na bodźce, ma trudności z mobilizacją do działania; osoby z obniżonym napięciem mięśniowym mogą mieć kłopot $\mathrm{z}$ odpowiednim tonusem [...];

- nadreaktywność występująca na przemian z obniżoną aktywnością" (Klimek-Markowicz 2016, s. 295).

Zadaniem drugiego bloku funkcjonalnego - zespołu przetwarzania jest „odbieranie, przetwarzanie i przechowywanie informacji” (Klimek-Markowicz 2016, s. 290). Jednostka skoncentrowana na określonym bodźcu, np. dźwiękowym, prawidłowo go odbiera dzięki zmysłowi słuchu, interpretuje go w mózgu oraz zapamiętuje. Trzeci natomiast blok funkcjonalny - zespół realizacji ,jest odpowiedzialny za programowanie czynności oraz regulowanie i kontrolowanie złożonych form psychiki. Jego funkcje obejmują zamiar, tworzenie planu, ocenę efektu, kontrolowanie przebiegu planu, orientację w aktualnej i przyszłej sytuacji, wnioskowanie, koncepcje, myślenie [...]. Blok ten obejmuje również planowanie sekwencji ruchów dowolnych" (Klimek-Markowicz 2016, s. 290).

Kiedy mamy do czynienia z pracą dźwiękiem, rytmem, melodią dominującym kanałem odbioru jest słuch. „Dla osób z głębszą niepełnosprawnością intelektualną jest to jednak trudny kanał percepcyjny - eksteroreceptywny, czyli odległy i mocno związany z symbolami" (Klimek-Markowicz 2016, s. 298). Dźwięk bowiem wymaga wzmożonej koncentracji, uruchomionej wyobraźni oraz kojarzenia z obrazem.

Dźwiękowe aktywizowanie uczniów z niepełnosprawnością intelektualną do wykonywania określonych, świadomych ruchów w przestrzeni związane jest ze świadomością schematu ciała oraz $\mathrm{z}$ orientacją $\mathrm{w}$ określonej przestrzeni. Świadomość schematu ciała osoby z niepełnosprawnością intelektualną jest utrudniona. Aleksandra Tomkiewicz-Bętkowska oraz Alicja Krztoń piszą: „Z. Przyrowski uważa, że pojęcie schematu ciała odnosi się do koncepcji własnej konstrukcji anatomicznej i zrozumienia, w jaki sposób różne części organizmu wprowadzają się w ruch. Jeśli jednostka nie posiada świadomości konfiguracji ciała oraz świadomości potencjału ruchu, wówczas nie jest zdolna do formułowania planu ruchu, wykonywania precyzyjnych zadań i osiągania zamierzonego celu" (Tomkiewicz-Bętkowska, Krztoń 2009, s. 26). K. Klimek-Markowicz natomiast wyjaśnia, iż „źródło orientacji w ciele leży w rozwoju odruchów, bodźcach czuciowych głębokich i powierzchniowych oraz $w$ ich integracji. Stanowi ona podstawę poznawania 
własnego ciała i otaczającej przestrzeni [...]. Na podstawie wymienionych czynników rozwija się orientacja w ciele, rozumiana nie jako wiedza, lecz świadomość (czyli nie tyle mam wyuczony gest wskazywania głowy, ile czuję ją oraz to, co się z nią dzieje; kulając się po pokoju, wiem, gdzie się zatrzymać, żeby nie uderzyć w szafę)" (Klimek-Markowicz 2016, s. 334). Rozumienie schematu własnego ciała warunkuje prawidłowe rozróżnianie kierunków w przestrzeni oraz właściwe poruszanie się w przestrzeni. Warto zwrócić uwagę, jak uczeń z niepełnosprawnością intelektualną pokonuje konkretną drogę, czyli ,jak wykonuje polecenia związane z przestrzenią - od prostych: Idź do okna, Połóź klocek na półce (badający obserwuje, czy dziecko od razu wie, gdzie położyć przedmiot, czy też szuka tego miejsca), po trudniejsze: Połóż klocek pod książka na pótce" (Klimek-Markowicz 2016, s. 335).

Poniżej przedstawię autorski model zajęć dźwiękowo-ruchowych dla uczniów z niepełnosprawnością intelektualną w stopniu umiarkowanym i znacznym.

\section{Model zajęć dźwiękowo-ruchowych - ogólna charakterystyka}

Powyższa część teoretyczna posłużyła do praktycznego opracowania modelu zajęć dźwiękowo-ruchowych prowadzonych w szkole specjalnej przez studentów Wydziału Nauk Pedagogicznych Uniwersytetu Kardynała Stefana Wyszyńskiego w Warszawie w ramach przedmiotu „Metodyka pracy rewalidacyjnej z osobami niepełnosprawnymi intelektualnie". Adresatem zajęć byli uczniowie z niepełnosprawnością intelektualną w stopniu umiarkowanym i znacznym, uczęszczający do III klasy szkoły podstawowej. Model zajęć dźwiękowo-ruchowych miał na celu aktywizowanie, prowokowanie określonego - prawidłowego i świadomego ruchu w przestrzeni poprzez świadomie dobrane i zastosowane dźwięki. Studenci prowadzili zajęcia regularnie raz w tygodniu przez okres trzech miesięcy, na każdy moduł poświęcając trzy spotkania.

Model zajęć składał się z czterech modułów:

- Moduł I. „Ruch w powietrzu - Piloci” - moduł akcentował dźwięki wysokie i niskie, które aktywizowały ruch do góry (pozycja stania z rękami uniesionymi do góry) i na dół (pozycja przysiadu);

- Moduł II. „Ruch na wodzie - Piraci” - moduł akcentował dźwięki głośne i ciche, które aktywizowały ruch mocny (pozycja dynamicznego bujania) i słaby (pozycja delikatnego bujania) na prawą stronę i na lewą stronę;

- Moduł III. „Ruch na ziemi - Wycieczkowicze” - moduł akcentował dźwięki długie i krótkie, które aktywizowały ruch do przodu (czynność chodzenia) i do tyłu (czynność cofnięcia o jeden krok);

- Moduł IV. „Ruch na ziemi - Piesi i kierowcy” - moduł akcentował dźwięki długie, krótkie i pauzę (brak ruchu/zatrzymanie ruchu). Dźwięki długie aktywizowały ruch do przodu (czynność chodzenia w przypadku pieszych/ czynność jazdy/biegania w przypadku kierowców). Dźwięki krótkie aktywizowały ruch do tyłu (czynność cofania w chodzeniu - w przypadku 
pieszych/czynność cofania w jeździe/bieganiu - w przypadku kierowców) oraz pauzę (pozycja bezruchu). Ponadto zostały zastosowane dźwięki wraz z obrazem, a mianowicie: dźwięki długie z obrazem (grafika strzałki w prawo z napisem „w prawo") oraz dźwięki długie z obrazem (grafika strzałki w lewo z napisem „w lewo"); dźwięki długie z obrazem (światło zielone z napisem „start”); dźwięki krótkie z obrazem (światło zielone z napisem „start”) oraz pauza z obrazem (światło czerwone z napisem „stop”). Dodatkowo wykorzystany został dźwięk wypowiadanych słów: „w prawo”, w „lewo”, „start”, „stop” oraz dźwięk otwieranej walizki.

\section{Moduł IV. „Ruch na ziemi - Piesi i kierowcy” - ogólna charakterystyka}

Na potrzeby niniejszego artykułu przedstawię IV moduł zajęć dźwiękowo-ruchowych zatytułowany: „Ruch na ziemi - Piesi i kierowcy”. Charakteryzuje się on większą złożonością od trzech poprzedzających go modułów, a mianowicie:

1. Zostały powielone wprowadzone wcześniej rodzaje dźwięku, rodzaje ruchu i kierunki ruchu, celem utrwalenia ich przez uczniów z niepełnosprawnością intelektualną.

2. Treści zostały ułożone w sposób koncentryczny i logiczny, a zatem pracę rozpoczęto od wiedzy i umiejętności, które uczniowie zdobyli w poprzednich modułach. Następnie stopniowo dostarczano uczniom nowych informacji, które były stosowane w praktyce, tym samym wiedza ich stawała się zrozumiała i operatywna.

3. Do zastosowanych rodzajów dźwięku, rodzajów ruchu i kierunków ruchu zostały dołączone: obraz (światło zielone, światło czerwone/grafika strzałki w prawo, grafika strzałki w lewo/napis „start”, napis „stop”/napis „w prawo", napis „w lewo”) oraz słowo werbalizowane („start”, „stop”, „w prawo", „w lewo").

Moduł IV. „Ruch na ziemi - Piesi i kierowcy” - aranżacja przestrzeni i atrybuty

Przestrzeń sali muzycznej została przeobrażona w przestrzeń ulicy. Studenci pracowali nad plastyczno-techniczną warstwą, która imitowała ulicę. Na podłodze wydzielili czarną taśmą skrzyżowanie oraz odchodzące od niego ulice wraz z chodnikiem dla pieszych. Przygotowali kartonowe czarno-białe pasy, które stanowiły przejście dla pieszych, styropianową sygnalizację świetlną - światło zielone opatrzyli wyrazem „start”, światło czerwone - wyrazem „stop” oraz styropianowe znaki drogowe: skręt w prawo - strzałka w prawo z wyrazem „w prawo" i skręt w lewo - strzałka w lewo z wyrazem „w lewo". Atrybutem kierowcy była kartonowa kierownica, a pieszego - walizka. Wszyscy uczniowie przyjęli rolę pieszych, a następnie kierowców samochodów. 
Moduł IV. „Ruch na ziemi - Piesi i kierowcy” - aktywizowanie ruchu w przestrzeni okołoosobowej - uczniowie z niepełnosprawnością intelektualną $\mathrm{w}$ roli pieszych

Uczniowie przyjęli rolę pieszych. Każdy z nich był proszony, aby spostrzegł, gdzie jest jego walizka - z prawej czy z lewej strony. Pieszy odpowiadał, że walizka jest po lewej jego stronie. Następnie był proszony, aby ją chwycił i postawił z prawej strony, a potem, żeby ją chwycił i postawił przed sobą, a następnie, aby ją chwycił i postawił za sobą, i ponownie z prawej strony. $\mathrm{W}$ ten sposób uczeń rozwijał lub usprawniał osobistą orientację w przestrzeni okołoosobowej. Każde chwycenie, podniesienie i przestawienie walizki było aktywizowane dźwiękiem otwieranej walizki i krótką dyspozycją słowną.

Moduł IV. „Ruch na ziemi - Piesi i kierowcy” - aktywizowanie ruchu w przestrzeni bliskiej uczniowie z niepełnosprawnością intelektualną $\mathrm{w}$ roli pieszych

W kolejnym etapie pieszy był proszony o podniesienie walizki, która znajdowała się po jego prawej stronie. Gdy usłyszał dźwięki długie, trzymając walizkę w prawym ręku, i zobaczył światło zielone z napisem: „start”, i usłyszał wypowiedziane słowo: „start”, szedł - przechodził przez przejście dla pieszych. Gdy usłyszał dźwięki krótkie i zobaczył światło czerwone z napisem: „stop”, i usłyszał wypowiedziane słowo: „stop”, musiał się zatrzymać. Słysząc dźwięki długie, szedł chodnikiem, a kiedy nastąpiła pauza, musiał się zatrzymać i ponownie postawić walizkę zgodnie z dyspozycjami studentów.

Moduł IV. „Ruch na ziemi - Piesi i kierowcy” - aktywizowanie ruchu w przestrzeni bliskiej uczniowie z niepełnosprawnością intelektualną w roli kierowców

Uczniowie przyjęli rolę kierowców samochodów. Każdy kierowca trzymał przed sobą kierownicę. Gdy usłyszał dźwięki długie i zobaczył światło zielone z napisem: „start” oraz usłyszał wypowiedziane słowo: „start”, poruszał się w przestrzeni ulicy, biegnąc do przodu. Kiedy nastąpiła pauza oraz zobaczył światło czerwone z napisem: „stop” oraz usłyszał wypowiedziane słowo: „stop” - zatrzymywał się w bezruchu. Słysząc dźwięki krótkie i widząc światło zielone z napisem: „start” oraz słysząc słowo: „start”, kierowca cofał się. Gdy nastąpiła pauza i zobaczył światło czerwone z napisem: „stop” oraz usłyszał słowo: „stop” - przyjmował pozycję w bezruchu. Przy powyższych dyspozycjach, które ukierunkowywały ruch samochodowy, studenci posługiwali się znakami drogowymi - grafiką strzałki w prawo, z napisem „W prawo” oraz zwerbalizowaniem słowa: „w prawo" i grafiką strzałki w lewo, z napisem: „w lewo” oraz zwerbalizowaniem słowa: „w lewo”. Dyspozycje były modyfikowane, aby uczeń nie został wprowadzony w schemat ruchowy, który odtwarzałby w sposób nieświadomy i bezrefleksyjny.

Kierowca reagował określonym ruchem na skonkretyzowane dźwięki muzyczne, przy jednoczesnym zwróceniu uwagi wzrokowej na obraz (światło, znak 
drogowy, napis) i słuchowej - na wypowiadane przez studenta słowa („start”, „stop”, „w prawo”, „w lewo”). W ten sposób uczeń rozwijał i usprawniał osobistą orientację w przestrzeni bliskiej oraz stymulował percepcję słuchową i wzrokową.

Ćwiczenia modułu IV, których odbiorcami byli uczniowie z niepełnosprawnością intelektualną w stopniu umiarkowanym i znacznym, dotyczyły aktywizowania przede wszystkim dźwiękiem, jak również obrazem i werbalizowanym słowem prawidłowego i świadomego ruchu w przestrzeni, a tym samym aktywizowania ruchu w określonym kierunku w przestrzeni okołoosobowej i w przestrzeni bliskiej. O tych rodzajach przestrzeni i trudnościach w nich się pojawiających pisał Zbigniew Przyrowski. Zaburzenia orientacji w przestrzeni okołoosobowej charakteryzują się trudnościami w sięganiu po przedmiot i chwytaniu go, zaburzenia orientacji w przestrzeni bliskiej charakteryzują się natomiast trudnościami w ocenie odległości i ocenie położenia, problemami w poruszaniu się między przedmiotami oraz ograniczeniami w przestrzeni poznawczej (Przyrowski 1998, s. 145).

\section{Podsumowanie}

1. Uczestnikami trzymiesięcznego cyklu zajęć dźwiękowo-ruchowych, składającego się z czterech modułów: I. „Ruch w powietrzu - Piloci”, II. „Ruch na wodzie - Piraci”, III. „Ruch na ziemi - Wycieczkowicze”, IV. „Ruch na ziemi - Piesi i kierowcy", byli uczniowie z niepełnosprawnością intelektualną w stopniu umiarkowanym i znacznym (III klasa szkoły podstawowej). Prowadzącymi zajęcia byli studenci Wydziału Nauk Pedagogicznych Uniwersytetu Kardynała Stefana Wyszyńskiego w Warszawie.

2. W pełnym cyklu zajęć dźwiękowo-ruchowych wykorzystano określone dźwięki: wysokie - niskie, długie - krótkie oraz ciche - głośne. Rozwijano i usprawniano określone kierunki ruchu: do góry - na dól, w prawo - w lewo oraz do przodu - do tyłu. Dodatkowo posłużono się prostym obrazem, grafiką słowa oraz słowem werbalizowanym.

3. Przedstawiono w sposób szczegółowy IV moduł zajęć dźwiękowo-ruchowych, w którym uczniowie z niepełnosprawnością intelektualną bardzo chętnie przyjęli rolę pieszych, a następnie kierowców samochodów. Dokonano aranżacji przestrzeni oraz wytworzenia podstawowych atrybutów pieszego i kierowcy.

4. Moduł IV zajęć dźwiękowo-ruchowych posłużył do zaprezentowania znaczenia określonych dźwięków i stopniowego, systematycznego aktywizowania ruchu dziecka $\mathrm{z}$ niepełnosprawnością intelektualną - ruchu refleksyjnego, intencjonalnego, który wyznaczał prawidłowy kierunek poruszania się $\mathrm{w}$ przestrzeni.

5. Za punkt wyjścia posłużyło wstępne poznanie mocy poznawczej ucznia, a zatem jego potencjału edukacyjnego, jak również ograniczeń w jego rozwoju psychoruchowym. Każdy student zapoznał się ze szczegółową 
charakterystyką psychoruchową ucznia z niepełnosprawnością intelektualną w stopniu umiarkowanym i znacznym, metodyką pracy edukacyjnej i rewalidacyjnej z uczniem, a następnie razem z grupą opracował model zajęć dźwiękowo-ruchowych, zgodnie z zasadami koncentrycznego i logicznego uporządkowania materiału merytorycznego oraz stopniowania trudności i systematyczności w trakcie realizacji pomysłu.

\section{Bibliografia}

Abramowiczówna Z. (1960). Słownik grecko-polski. Warszawa: Wydawnictwo Naukowe PWN.

Chyła-Szypułowa I. (2009). Aktywność artystyczna dzieci. W: Karczewska J., Kwaśniewska M. (red.). Dziecko sześcioletnie w szkole. Kielce: Wydawnictwo Pedagogiczne ZNP.

Klimek-Markowicz K. (2016). Spojrzenie neuropsychologiczne. W: Kielin J., Klimek-Markowicz K. Krok po kroku. Nauczanie i terapia dzieciz umiarkowana, znaczna i głęboka niepetnosprawnością intelektualną. Sopot: Gdańskie Wydawnictwo Psychologiczne.

Konieczna E. J. (2014). Arteterapia w teorii i praktyce. Kraków: Oficyna Wydawnicza „Impuls".

Kupisiewicz Cz., Kupisiewicz M. (2009). Słownik Pedagogiczny. Warszawa: Wydawnictwo Naukowe PWN.

Krzywoń D. (2008). Kraina kreatywności - sposoby przeciwdziałania rutynie w pracy z dziećmi poprzez ekspresje twórcza i artystyczna. Sosnowiec: Oficyna Wydawnicza „Humaintas”.

Makris M., Umiastowska D. (2001). Rozwój fizyczny i motoryczny dziecka w wieku przedszkolnym. Szczecin: Wydawnictwo Naukowe Uniwersytetu Szczecińskiego.

Nordoff P., Robbins C. (2008). Terapia muzyka $w$ pracy $z$ dziećmi niepetnosprawnymi. Historia, metoda i praktyka. Kraków: Oficyna Wydawnicza „Impuls”.

Przyrowski Z. (1998). Dysfunkcje integracji sensorycznej i deficyty fragmentaryczne w zespole mózgowego porażenia dziecięcego. Warszawa: Wydawnictwa Szkolne i Pedagogiczne.

Stegemann T. (2015). Strategie i profile terapeutyczne. W: Stegemann T., Hitzeler M., Blotevogel M. (red.). Arteterapie dla dzieci i młodzieży. Muzykoterapia, choreoterapia, terapia sztuką. Gdańsk: Wydawnictwo Harmonia.

Tomkiewicz-Bętkowska A., Krztoń A. (2009). ABC pedagoga specjalnego. Podręcznik dla nauczycieli ze specjalnym przygotowaniem pedagogicznym pracujacych $z$ dziećmi niepetnosprawnymi, dla studentów kierunków pedagogicznych oraz dla osób zainteresowanych kształceniem integracyjnym. Kraków: Oficyna Wydawnicza „Impuls”. 


\title{
MOVEMENT SOUND ACTIVATION IN SPACE: MODEL OF WORKING WITH STUDENTS WITH COGNITIVE CHALLENGES
}

\begin{abstract}
The article presents the activation of movement in space using various types of sounds, presenting the author's model of working with children with moderate and severe intellectual disabilities. The first theoretical part, in which the importance of music and sound for development and therapy was presented, became an introduction to the second applied part, in which sounds activating movement and moving in the space of students with intellectual disabilities were presented. Using the proprietary model of sound and movement classes, the recipients of which were students with intellectual disabilities, the characteristics of the four modules of the classes were specified, detailing Module IV entitled Movement on Earth - Pedestrians and drivers. Its primary goal was to activate and provoke specific - correct and intentional movement in space through consciously selected and used sounds. The movement was activated by a specific type of sound, enriched with a simple picture and word - written and spoken, thanks to which every student with disability experimentally gained knowledge and the ability to understand space and consciously move in it.
\end{abstract}

Keywords: music; sound; movement in space; sound activation; student with intellectual disability.

Kinga Krawiecka - doktor nauk humanistycznych w dyscyplinie pedagogika, pedagog rewalidacyjny. Jej zainteresowania naukowe oscylują wokół teorii i praktyki edukacji i terapii osób z niepełnosprawnością intelektualną. Inspirowana sztuką podejmuje tematykę plastycznego i teatralnego procesu tworzenia i odtwarzania w działalności edukacyjnej i terapeutycznej z dziećmi, młodzieżą i osobami dorosłymi z niepełnosprawnością intelektualną. Adres korespondencyjny: Wydział Nauk Pedagogicznych UKSW, ul. Wóycickiego 1/3, 01-938 Warszawa. Adres e-mailowy: k.krawiecka@uksw.edu.pl. 